\title{
Article \\ Synthesis of Chitosan-Coated Silver Nanoparticle Bioconjugates and Their Antimicrobial Activity against Multidrug-Resistant Bacteria
}

\author{
Surbhi Shinde ${ }^{1}$, Veronica Folliero ${ }^{1}$, Annalisa Chianese ${ }^{1}{ }^{\mathbb{D}}$, Carla Zannella ${ }^{1} \mathbb{(}$, Anna De Filippis ${ }^{1}$, \\ Luigi Rosati ${ }^{2}{ }^{1}$, Marina Prisco ${ }^{2}$, Annarita Falanga ${ }^{3}{ }^{10}$, Avinash Mali ${ }^{1}$, Marilena Galdiero ${ }^{1} \mathbb{D}$, \\ Massimiliano Galdiero $1, *$ (I) and Gianluigi Franci ${ }^{4,5, *(\mathbb{D})}$
}

check for updates

Citation: Shinde, S.; Folliero, V.; Chianese, A.; Zannella, C.; De Filippis, A.; Rosati, L.; Prisco, M.; Falanga, A.; Mali, A.; Galdiero, M.; et al. Synthesis of Chitosan-Coated Silver Nanoparticle Bioconjugates and Their Antimicrobial Activity against Multidrug-Resistant Bacteria. Appl. Sci. 2021, 11, 9340. https:// doi.org/10.3390/app11199340

Academic Editor: Patrizia Messi

Received: 12 May 2021

Accepted: 6 October 2021

Published: 8 October 2021

Publisher's Note: MDPI stays neutral with regard to jurisdictional claims in published maps and institutional affiliations.

Copyright: (c) 2021 by the authors. Licensee MDPI, Basel, Switzerland. This article is an open access article distributed under the terms and conditions of the Creative Commons Attribution (CC BY) license (https:/ / creativecommons.org/licenses/by/ $4.0 /)$.
1 Department of Experimental Medicine, University of Campania "Luigi Vanvitelli", 80138 Naples, Italy; surbhi.shinde@unicampania.it (S.S.); veronica.folliero@unicampania.it (V.F.); annalisa.chianese@unicampania.it (A.C.); carla.zannella@unicampania.it (C.Z.); anna.defilippis@unicampania.it (A.D.F.); avinash.mali@unicampania.it (A.M.); marilena.galdiero@unicampania.it (M.G.)

2 Department of Biology, University of Naples “Federico II", 80126 Naples, Italy; luigi.rosati@unina.it (L.R.); marina.prisco@unina.it (M.P.)

3 Department of Agricultural Science, University of Naples "Federico II", 80055 Naples, Italy; annarita.falanga@unina.it

4 Department of Medicine, Surgery and Dentistry "Scuola Medica Salernitana", University of Salerno, 84081 Baronissi, Italy

5 Department of Sanitary Hygiene and Evaluative Medicine U.O.C. Clinical and Microbiological Pathology, Ruggi D'Aragona Medical School of Salerno, University Hospital of S. Giovanni di Dio, 84131 Salerno, Italy

* Correspondence: massimiliano.galdiero@unicampania.it (M.G.); gfranci@unisa.it (G.F.)

Abstract: The increase in multidrug-resistant bacteria represents a true challenge in the pharmaceutical and biomedical fields. For this reason, research on the development of new potential antibacterial strategies is essential. Here, we describe the development of a green system for the synthesis of silver nanoparticles (AgNPs) bioconjugated with chitosan. We optimized a Prunus cerasus leaf extract as a source of silver and its conversion to chitosan-silver bioconjugates ( $\mathrm{CH}-\mathrm{AgNPs}$ ). The AgNPs and $\mathrm{CH}-\mathrm{AgNPs}$ were characterized using transmission electron microscopy (TEM), dynamic light scattering (DLS), Fourier transform infrared spectroscopy (FT-IR), ultraviolet-visible spectroscopy (UV-Vis), and zeta potential measurement (Z-potential). The cytotoxic activity of AgNPs and CH-AgNPs was assessed on Vero cells using the 3-[4.5-dimethylthiazol-2-yl]-2.5-diphenyltetrazolium bromide (MTT) cell proliferation assay. The antibacterial activity of AgNPs and CH-AgNPs synthesized using the green system was determined using the broth microdilution method. We evaluated the antimicrobial activity against standard ATCC and clinically isolated multisensitive (MS) and multidrugresistant bacteria (MDR) Escherichia coli (E. coli), Enterococcus faecalis (E. faecalis), Klebsiella pneumonia (K. pneumoniae), and Staphylococcus aureus (S. aureus), using minimum inhibitory concentration (MIC) assays and the broth dilution method. The results of the antibacterial studies demonstrate that the silver chitosan bioconjugates were able to inhibit the growth of MDR strains more effectively than silver nanoparticles alone, with reduced cellular toxicity. These nanoparticles were stable in solution and had wide-spectrum antibacterial activity. The synthesis of silver and silver chitosan bioconjugates from Prunus cerasus leaf extracts may therefore serve as a simple, ecofriendly, noncytotoxic, economical, reliable, and safe method to produce antimicrobial compounds with low cytotoxicity.

Keywords: silver nanoparticle; chitosan-silver nanoparticle; multidrug-resistant bacteria; green synthesis

\section{Introduction}

Multidrug-resistant bacteria (MDR), also known as "superbugs", represent a serious threat to our society. Over time, microorganisms are gaining resistance to the available 
antimicrobials, and there is an urgent need to develop innovative and effective antimicrobial approaches. To date, specific resistance has developed against most antibiotics [1]. There are two main problems that should be addressed: (i) the lack of new classes of antibiotics; (ii) the shortening window between the commercial use of new variants of old antibiotics and the outbreak of resistant bacterial strains [2]. In recent years, antibiotics have been given in high doses due to increasing drug resistance, and the resulting toxicity has focused the attention on the need to develop and define innovative and effective antimicrobial treatments $[3,4]$.

In the last 20 years, the emergence of nanotechnology has been allowing for the development of new potential alternative antimicrobial agents to be used against bacterial infections and for drug delivery, in both in vitro and in vivo models [5,6]. Among the metal nanoparticles, silver nanoparticles are studied for their excellent antimicrobial properties, which are due to silver ions inhibiting bacterial DNA replication and damaging cytoplasmic membrane, which causes cell death after a decrease in ATP levels [6]. These observations suggest that nanoparticles can be effective against both Gram-positive and Gram-negative bacteria. There are many advantages of using silver nanoparticles (AgNPs) as antimicrobial agents: they have high antibacterial activity based on multiple mechanisms of action and can help in overcoming the resistance of microorganisms to conventional antibiotics [7]. In addition, AgNPs can be synthesized with simpler and cheaper methods using chemical reactions and biosynthesis [8]. In the study of Rozykulyyeva et al., Punica granatum AgNPs showed high antibacterial activity on different oral pathogens, such as Actinobacillus actinomycetemcomitans, Pseudomonas aeruginosa, E. faecalis, and S. aureus [9]. Likewise, Ying Loo et al. reported a high antibacterial effect of pu-erh tea AgNPs against E. coli, K. pneumoniae, Salmonella typhimurium, and Salmonella enteritidis, with minimum inhibitory concentrations (MICs) of between 7.8 and $3.9 \mu \mathrm{g} / \mathrm{mL}$ recorded [10].

AgNPs simultaneously act on cell wall and cell permeability, impair metabolic pathways, induce DNA damage, inhibit protein synthesis and function, and promote the formation of reactive oxygen species [6,11]. Nanoparticles can be synthesized using various mechanisms and chemical and physical methods. The most cost effective, ecofriendly, and nonhazardous methods for synthesizing nanoparticles are those characterized as green approaches or green nanoparticle synthesis [12].

Green synthesis of nanoparticles employs processes using natural materials and is more innovative and cheaper than previous strategies $[13,14]$. The widespread availability of biological resources and the simplicity of the methodology are key benefits promoting the popular use of green chemistry for metal nanoparticle synthesis [15,16]. Presently, phytonanotechnology has been presented as a new avenue for nanoparticle synthesis with applications in the biomedical and environmental fields [17].

The low toxicity, potential antimicrobial activity, and opportunity for green synthesis of nanoparticles herald a new era of their production. Natural components for AgNP production with improved antimicrobial properties have recently been proposed, with one example being chitosan [18-20]. Chitosan is a natural polysaccharide biopolymer which consists of two monosaccharides, GlcNAc and D-glucosamine (GlcN), linked together by $\beta-(1 \rightarrow 4)$ glycosidic bonds [21]. Researchers have determined that chitosan from sweet cherry (Prunus avium L.) can inhibit the growth of microorganisms [22,23]. The main properties of chitosan are its nontoxicity, biocompatibility, biodegradability, and hemostatic properties. Due to these effects, polyelectrolytes such as chitosan have been used in various ways to stabilize nanoparticles and to increase their antimicrobial properties upon successful formation of polymer-metal ion complexes [24]. Previous studies have shown that chitosan can stabilize nanoparticle surfaces and thereby modulate cytotoxicity. Moreover, AgNPs coated with chitosan demonstrated high efficiency in killing common Gram-positive and Gram-negative bacteria as well as some fungi [25].

Considering the importance of metal nanoparticle synthesis, especially those of silver synthesized using different plants, the aim of this study was to develop a method for green synthesis of silver nanoparticles (AgNPs) with stable chitosan-coated silver nanoparticles 
(CH-AgNPs) using Prunus cerasus leaf extracts. Investigation of their antimicrobial activity has focused on different Gram-positive and Gram-negative strains of bacteria, paving the way for the possibility for their translation into clinical settings as an alternative antimicrobial strategy.

\section{Materials and Methods}

\subsection{Tested Microorganisms}

E. coli (ATCC 11229), E. faecalis (ATCC 29212), K. pneumoniae (ATCC 10031), and S. aureus (ATCC 6538) were obtained from the American Type Culture Collection (ATCC, Manassas, VA, USA. The multidrug-resistant (MDR) clinical isolates and multisensitive (MS) clinical isolates were collected from the "Vanvitelli" University Hospital based in Naples. Bacteria were identified via MALDI-TOF MS (Bruker Daltonics, Bremen, Germany) and the antibiotic resistance patterns were evaluated using a BD Phoenix system (Becton Dickinson, USA). The antibiotic resistance profile of the ATCC bacterial strains and clinical isolates used in the study are reported in Tables 1 and 2, respectively.

Table 1. Antibiotic resistance profile of the ATCC bacterial strains: S. aureus, E. faecalis, E. coli, and K. pneumoniae.

\begin{tabular}{|c|c|c|}
\hline \multicolumn{3}{|c|}{ Antibiotic Resistance Profile of the ATCC Bacterial Strains } \\
\hline \multicolumn{3}{|c|}{ Staphylococcus aureus ATCC 6538} \\
\hline ANTIBIOTICS & MIC (mg/L) & INTERPRETATION \\
\hline Fusidic acid & $\leq 0.5$ & $\mathrm{~S}$ \\
\hline Daptomycin & $\overline{0} .25$ & S \\
\hline Erythromycin & $\leq 0.25$ & S \\
\hline Fosfomycin & $\leq 8$ & S \\
\hline Gentamicin & $\leq 0.5$ & S \\
\hline Linezolid & 2 & S \\
\hline Levofloxacin & $\leq 0.12$ & S \\
\hline Oxacillin & $\leq 0.25$ & S \\
\hline Teicoplanin & $\leq 0.5$ & S \\
\hline Tetracycline & $\leq 1$ & S \\
\hline Tigecycline & $\leq \overline{0} .12$ & S \\
\hline Trimethoprim/sulfamethoxazole & $\leq 10$ & $S$ \\
\hline Vancomycin & $\leq 0.5$ & $S$ \\
\hline Penicillin & $\leq 0.03$ & S \\
\hline Rifampicin & $\leq 0.03$ & S \\
\hline \multicolumn{3}{|c|}{ Enterococcus faecalis АТСС 29212} \\
\hline Ampicillin & $\leq 2$ & S \\
\hline Gentamicin/syn & $\leq 500$ & S \\
\hline Imipenem & $\leq 1$ & S \\
\hline Linezolid & 2 & $S$ \\
\hline Teicoplanin & $\leq 0.5$ & S \\
\hline Tigecycline & $\leq 0.12$ & S \\
\hline Vancomycin & 2 & $S$ \\
\hline Cefuroxime & $\leq 64$ & $\mathrm{R}$ \\
\hline \multicolumn{3}{|c|}{ Escherichia coli ATCC 11229} \\
\hline Amikacin & $\leq 2$ & $S$ \\
\hline Amoxicillin/clavulanate & $\leq 2$ & S \\
\hline Ampicillin & $\leq 8$ & S \\
\hline Cefepime & $\leq 1$ & S \\
\hline Cefotaxime & $\leq 1$ & S \\
\hline Ceftazidime & $\leq 1$ & $S$ \\
\hline Cefuroxime & $\overline{4}$ & S \\
\hline Ciprofloxacin & $\leq 0.25$ & S \\
\hline Ertapenem & $\leq 0.5$ & $S$ \\
\hline Fosfomycin & $\leq 16$ & $S$ \\
\hline
\end{tabular}


Table 1. Cont.

\begin{tabular}{ccc}
\hline \multicolumn{1}{c}{ Antibiotic Resistance Profile of the ATCC Bacterial Strains } & \\
\hline Gentamicin & $\leq 1$ & $\mathrm{~S}$ \\
Imipenem & $\leq 0.25$ & $\mathrm{~S}$ \\
Levofloxacin & $\leq 0.5$ & $\mathrm{~S}$ \\
Meropenem & $\leq 0.25$ & $\mathrm{~S}$ \\
Piperacillin & 8 & $\mathrm{~S}$ \\
Piperacillin/tazobactam & $\leq 4$ & $\mathrm{~S}$ \\
Tobramycin & $\leq 1$ & $\mathrm{~S}$ \\
Trimethoprim/sulfamethoxazole & $\leq 20$ & $\mathrm{~S}$ \\
Tigecycline & $\leq 0.5$ & $\mathrm{~S}$ \\
& Klebsiella pneumoniae ATCC 10031 & \\
Ciprofloxacin & $\leq 0.25$ & $\mathrm{~S}$ \\
Fosfomycin & $\leq 16$ & $\mathrm{~S}$ \\
Ampicillin & $\leq 8$ & $\mathrm{~S}$ \\
Gentamicin & $\leq 1$ & $\mathrm{~S}$ \\
Amikacin & $\leq 20$ & $\mathrm{~S}$ \\
Cefepime & $\leq 2$ & $\mathrm{~S}$ \\
Cefotaxime & $\leq 2$ & $\mathrm{~S}$ \\
Ceftazidime & $\leq 1$ & $\mathrm{~S}$ \\
Ertapenem & $\leq 1$ & $\mathrm{~S}$ \\
Imipenem & $\leq 1$ & $\mathrm{~S}$ \\
Meropenem & $\leq 0.5$ & $\mathrm{~S}$ \\
Trimethoprim/sulfamethoxazole & $\mathrm{S}$ \\
Piperacillin/tazobactam & $\leq 0.25$ & $\mathrm{~S}$ \\
Colistin & $\leq 4$ & $\mathrm{~S}$ \\
\hline
\end{tabular}

Table 2. Antibiotic resistance profile of the clinical isolates: S. aureus MS, S. aureus MDR, E. faecalis MS, E. faecalis MDR, E. coli MS, E. coli MDR, K. pneumoniae MS, and K. pneumoniae MDR.

\begin{tabular}{|c|c|c|}
\hline \multicolumn{3}{|c|}{ Antibiotic Resistance Profile of the Clinical Isolated Bacteria } \\
\hline \multicolumn{3}{|c|}{ Staphylococcus aureus MS } \\
\hline Fusidic acid & $\leq 0.5$ & $S$ \\
\hline Daptomycin & 0.25 & $S$ \\
\hline Erythromycin & $\leq 0.25$ & $S$ \\
\hline Fosfomycin & $\leq 8$ & $S$ \\
\hline Gentamicin & $\leq 0.5$ & $S$ \\
\hline Linezolid & 2 & $S$ \\
\hline Levofloxacin & $\leq 0.12$ & $S$ \\
\hline Oxacillin & $\leq 0.25$ & $S$ \\
\hline Teicoplanin & $\leq 0.5$ & $S$ \\
\hline Tetracycline & $\leq 1$ & $S$ \\
\hline Tigecycline & $\leq \overline{0} .12$ & $S$ \\
\hline Trimethoprim/sulfamethoxazole & $\leq 10$ & $S$ \\
\hline Vancomycin & $\leq 0.5$ & $S$ \\
\hline Penicillin & $\leq 0.03$ & $S$ \\
\hline Fusidic acid & $\leq 0.5$ & $S$ \\
\hline Daptomycin & 0.25 & $S$ \\
\hline Erythromycin & $\leq 0.25$ & $S$ \\
\hline \multicolumn{3}{|c|}{ Staphylococcus aureus MDR } \\
\hline Fusidic acid & $\leq 0.5$ & $S$ \\
\hline Daptomycin & 0.25 & $S$ \\
\hline Erythromycin & $>4$ & $\mathrm{R}$ \\
\hline Fosfomycin & $>64$ & $\mathrm{R}$ \\
\hline Gentamicin & $>8$ & $\mathrm{R}$ \\
\hline Linezolid & 2 & $\mathrm{~S}$ \\
\hline Levofloxacin & $\geq 8$ & $\mathrm{R}$ \\
\hline Oxacillin & $>2$ & $\mathrm{R}$ \\
\hline
\end{tabular}


Table 2. Cont.

\begin{tabular}{|c|c|c|}
\hline \multicolumn{3}{|c|}{ Antibiotic Resistance Profile of the Clinical Isolated Bacteria } \\
\hline Teicoplanin & $\leq 0.5$ & S \\
\hline Tetracycline & $\leq 1$ & S \\
\hline Tigecycline & $\leq \overline{0} .12$ & $\mathrm{~S}$ \\
\hline Trimethoprim/sulfamethoxazole & 20 & $S$ \\
\hline Vancomycin & $\leq 0.5$ & $\mathrm{~S}$ \\
\hline Penicillin & $>0.25$ & $\mathrm{R}$ \\
\hline Rifampicin & $>2$ & $\mathrm{R}$ \\
\hline \multicolumn{3}{|c|}{ Enterococcus faecalis MS } \\
\hline Ampicillin & $\leq 2$ & S \\
\hline Gentamicin/syn & $\leq 500$ & $S$ \\
\hline Imipenem & $\leq 2$ & $\mathrm{~S}$ \\
\hline Linezolid & 2 & S \\
\hline Teicoplanin & $\leq 0.5$ & $S$ \\
\hline Tigecycline & $\leq 0.25$ & $S$ \\
\hline Vancomycin & 2 & $S$ \\
\hline Cefuroxime & $\leq 64$ & $\mathrm{R}$ \\
\hline \multicolumn{3}{|c|}{ Enterococcus faecalis MDR } \\
\hline Ampicillin & $>8$ & $\mathrm{R}$ \\
\hline Gentamicin/syn & $\geq 500$ & $\mathrm{R}$ \\
\hline Imipenem & $>8$ & $\mathrm{R}$ \\
\hline Linezolid & 2 & $S$ \\
\hline Teicoplanin & $\leq 0.5$ & $\mathrm{~S}$ \\
\hline Tigecycline & $>0.25$ & $\mathrm{R}$ \\
\hline Vancomycin & 2 & $S$ \\
\hline Cefuroxime & $\leq 64$ & $\mathrm{R}$ \\
\hline \multicolumn{3}{|c|}{ Escherichia coli MS } \\
\hline Amikacin & $\leq 2$ & $S$ \\
\hline Amoxicillin/clavulanate & $\leq 2$ & $S$ \\
\hline Ampicillin & $\leq 8$ & $S$ \\
\hline Cefepime & $\bar{x}_{1}$ & $\mathrm{~S}$ \\
\hline Cefotaxime & $\leq 1$ & $S$ \\
\hline Ceftazidime & $\overline{\leq} 1$ & $S$ \\
\hline Cefuroxime & 4 & $S$ \\
\hline Ciprofloxacin & $\leq 0.25$ & $S$ \\
\hline Ertapenem & $\leq 0.5$ & $S$ \\
\hline Fosfomycin & $\leq 16$ & $S$ \\
\hline Gentamicin & $\leq 1$ & $\mathrm{~S}$ \\
\hline Imipenem & $\leq \overline{0} .25$ & $S$ \\
\hline Levofloxacin & $\leq 0.5$ & $\mathrm{~S}$ \\
\hline Meropenem & $\leq 0.25$ & $S$ \\
\hline Piperacillin & 8 & $S$ \\
\hline Piperacillin/tazobactam & $\leq 4$ & $S$ \\
\hline Tobramycin & $\overline{\leq} 1$ & $S$ \\
\hline Trimethoprim/sulfamethoxazole & $\leq 20$ & S \\
\hline Tigecycline & $\leq 0.5$ & $S$ \\
\hline \multicolumn{3}{|c|}{ Escherichia coli MDR } \\
\hline Amikacin & $>16$ & $\mathrm{R}$ \\
\hline Amoxicillin/clavulanate & $>32 / 2$ & $\mathrm{R}$ \\
\hline Ampicillin & $>8$ & $\mathrm{R}$ \\
\hline Cefepime & $>8$ & $\mathrm{R}$ \\
\hline Cefotaxime & $>4$ & $\mathrm{R}$ \\
\hline Ceftazidime & $>8$ & $\mathrm{R}$ \\
\hline Cefuroxime & $>8$ & $\mathrm{R}$ \\
\hline Ciprofloxacin & $>1$ & $\mathrm{R}$ \\
\hline Ertapenem & $\leq 0.25$ & $S$ \\
\hline Fosfomycin & $\leq 16$ & $S$ \\
\hline Gentamicin & $>4$ & $\mathrm{R}$ \\
\hline Imipenem & $\leq 0.25$ & $\mathrm{R}$ \\
\hline
\end{tabular}


Table 2. Cont.

\begin{tabular}{|c|c|c|}
\hline \multicolumn{3}{|c|}{ Antibiotic Resistance Profile of the Clinical Isolated Bacteria } \\
\hline Levofloxacin & $>2$ & $\mathrm{R}$ \\
\hline Meropenem & $\leq 0.125$ & $\mathrm{~S}$ \\
\hline Piperacillin & $>16$ & $\mathrm{R}$ \\
\hline Piperacillin/tazobactam & $>16 / 4$ & $\mathrm{R}$ \\
\hline Tobramycin & $>4$ & $\mathrm{R}$ \\
\hline Trimethoprim/sulfamethoxazole & $\leq 1 / 19$ & $\mathrm{~S}$ \\
\hline Tigecycline & 1 & $\mathrm{R}$ \\
\hline \multicolumn{3}{|c|}{ Klebsiella pneumoniae MS } \\
\hline Ciprofloxacin & $\leq 0.25$ & $S$ \\
\hline Fosfomycin & $\leq 16$ & $\mathrm{~S}$ \\
\hline Gentamicin & $\leq 1$ & $\mathrm{~S}$ \\
\hline Trimethoprim/sulfamethoxazole & $\overline{\leq} 20$ & $\mathrm{~S}$ \\
\hline Amikacin & $\leq 2$ & $S$ \\
\hline Ampicillin & $\leq 8$ & $\mathrm{~S}$ \\
\hline Amoxicillin/clavulanate & $\leq 2$ & $S$ \\
\hline Cefepime & $\leq 1$ & $S$ \\
\hline Cefotaxime & $\leq 1$ & $S$ \\
\hline Ceftazidime & $\leq 1$ & $S$ \\
\hline Ertapenem & $\leq 0.5$ & $\mathrm{~S}$ \\
\hline Imipenem & $\leq 0.25$ & $S$ \\
\hline Meropenem & $\leq 0.25$ & $\mathrm{~S}$ \\
\hline Piperacillin/tazobactam & $\leq 4$ & $\mathrm{~S}$ \\
\hline Colistin & $\leq 0.5$ & $S$ \\
\hline \multicolumn{3}{|c|}{ Klebsiella pneumoniae MDR } \\
\hline Ciprofloxacin & $\geq 4$ & $\mathrm{R}$ \\
\hline Fosfomycin & $\overline{6} 4$ & $\mathrm{~S}$ \\
\hline Gentamicin & $\leq 1$ & $S$ \\
\hline Trimethoprim/sulfamethoxazole & $\geq 320$ & $\mathrm{R}$ \\
\hline Amikacin & $\geq 64$ & $\mathrm{R}$ \\
\hline Amoxicillin/clavulanate & $\geq 32$ & $\mathrm{R}$ \\
\hline Ampicillin & $>8$ & $\mathrm{R}$ \\
\hline Cefepime & $\geq 64$ & $\mathrm{R}$ \\
\hline Cefotaxime & $\geq 64$ & $\mathrm{R}$ \\
\hline Ceftazidime & $\geq 64$ & $\mathrm{R}$ \\
\hline Ertapenem & $\geq 8$ & $\mathrm{R}$ \\
\hline Imipenem & $\geq 16$ & $\mathrm{R}$ \\
\hline Meropenem & $\geq 16$ & $\mathrm{R}$ \\
\hline Piperacillin/tazobactam & $\geq 128$ & $\mathrm{R}$ \\
\hline Colistin & $\leq 0.5$ & $S$ \\
\hline
\end{tabular}

\subsection{Preparation of Chitosan Solution}

Chitosan solution was prepared by dissolving chitosan (from shrimp shells, $\geq 75 \%$ deacetylated, C3646) powder to $0.1 \%(\mathrm{~m} / \mathrm{v})$ in $1 \%$ aqueous acetic acid solution (A6283) with subsequent stirring to promote dissolution. All the reagents were analytical grade, purchased from Sigma-Aldrich and were used without further purification.

\subsection{Preparation of Plant Extract and Synthesis of Silver Nanoparticles}

Fresh leaves grown by a local farmer under biological growth conditions were collected and then washed thoroughly with tap water three times followed by double sterile distilled water to remove dust particles. After washing, $10 \mathrm{~g}$ of fresh plant leaves were boiled in $100 \mathrm{~mL}$ of sterile distilled water in a $500 \mathrm{~mL}$ Erlenmeyer flask for $20 \mathrm{~min}$. The extract was separated from the leaves via decantation and then filtered with Whatman filter paper No. 1. Thereafter, $5 \mathrm{~mL}$ of leaf extract was diluted with $4.5 \mathrm{~mL}$ of double distilled water and treated with $0.5 \mathrm{~mL}$ of $1 \mathrm{mM}$ silver nitrate salt $\left(\mathrm{AgNO}_{3}, 99.8 \%\right.$, Sigma, St Louis, $\mathrm{MO}$, USA). The color change reaction was observed, indicating $\mathrm{pH}$ 6. This color change is indicative of nanoparticle formation, and the reaction mixture was then stored at room temperature 
for $24 \mathrm{~h}$ in the dark. The reaction mixture was then lyophilized to obtain nanoparticles in powder form. The lyophilization process was carried out in a freezer at $-55^{\circ} \mathrm{C}$ for $24 \mathrm{~h}$, followed by processing conditions at a chamber pressure of $1000 \mathrm{mbar}$ for $24 \mathrm{~h}$.

The Prunus cerasus plant materials were harvested from a local farmer in Caserta (Campania, Italy) and authenticated through molecular analysis of the internal transcribed spacer (ITS) region of nuclear ribosomal DNA (data not shown). No approvals were required for the study, which complied with all relevant regulations.

\subsection{Synthesis of Silver Chitosan Nanoparticles}

A $5 \mathrm{~mL}$ volume of leaf extract solution was combined with $3 \mathrm{~mL}$ of $1 \%$ chitosan solution (dissolved in acetic acid solution). Further, the reaction mixture was allowed to mix for $30 \mathrm{~min}$ and $1 \mathrm{~mL}$ of $1 \mathrm{mM}$ silver nitrate (Sigma-Aldrich, St Louis, MO, USA) solution was added dropwise to the reaction mixture while it was magnetically stirred at $70{ }^{\circ} \mathrm{C}$. Then, the reaction mixture was incubated for an additional $2 \mathrm{~h}$. The mixture changed from colorless to light yellow within $30 \mathrm{~min}$ and, finally, to dark yellowish brown after the completion of the reaction. This change in color indicates the formation of chitosan-coated silver nanoparticles ( $\mathrm{CH}$-AgNPs). The synthesis process was monitored by visual observation of the color change and agglomeration within a certain period of time (24-48 h). Furthermore, to obtain CH-AgNP powder, the mixture was lyophilized after $48 \mathrm{~h}$ of reaction. The reaction was treated at $-55^{\circ} \mathrm{C}$ for $24 \mathrm{~h}$ and subjected to a chamber pressure of $1000 \mathrm{mbar}$ for the next $24 \mathrm{~h}$. The dried powder was designated as $\mathrm{CH}-\mathrm{AgNPs}$ and stored for further study.

\subsection{UV-Vis Spectroscopy}

The optical properties of $\mathrm{CH}-\mathrm{AgNPs}$ were observed using a UV-Vis spectrophotometer. After the addition of leaf extracts to silver nitrate solution the spectra were taken and a blank (distilled water) was used as reference for baseline correction. The results were recorded with the Analytik Jena Specord 210 Plus190 (UV-Vis) at $1100 \mathrm{~nm}$. The spectrophotometer used synthetic quartz spectrophotometer cells $(190-2500 \mathrm{~nm}$, path length $10 \mathrm{~mm}$, volume $1.75 \mathrm{~mL}$ ). The measurements were collected at a wavelength range of between 200 and $800 \mathrm{~nm}$ at $1 \mathrm{~nm}$ resolution.

\subsection{Dynamic Light Scattering and Zeta Potential}

The size of AgNPs and CH-AgNPs was determined by dynamic light scattering (DLS) and the charge present on the surface of nanoparticles was determined using the Zetasizer Nanoseries (MALVERN Zetasizer Nano ZS, Malvern, UK). Zeta potentials were measured at $25^{\circ} \mathrm{C}$ and obtained data were analyzed using Zetasizer software.

\subsection{FT-IR Analysis}

Nanoparticles in dried powder form were characterized by Fourier transform infrared spectroscopy (JASCO FT/IR-4100). Spectra were taken in the range of $400-4000 \mathrm{~cm}^{-1}$ at a resolution of $4 \mathrm{~cm}^{-1}$. The data from the FTIR reveal information about functional groups which are present in the nanoparticles.

\subsection{Transmission Electron Microscopy Analysis}

For determining the exact size and morphology of the AgNPs and CH-AgNPs, transmission electron microscopy (FEI Tecnai G2, TEM) was used. For analysis, $5 \mu \mathrm{L}$ of AgNPs or $\mathrm{CH}-\mathrm{AgNPs}$ was placed onto carbon-coated copper microgrids; excess solution was removed using filter paper, and the specimens were dried at room temperature. Staining was performed using UranyLess (EMS, Hatfield, PA, USA) for 2 min at room temperature; the grids were blotted on filter paper then washed with distilled water and air dried at room temperature. Further, TEM observation was performed using a FEI Tecnai G2 operating at $120 \mathrm{kV}$, with images captured by FEI TEM Imaging and Analysis (version 4.7 SP3). 


\subsection{Cytotoxicity Assay}

In order to determine the efficacy and to provide biocompatibility of chitosan with AgNPs, we synthesized chitosan-coated silver nanoparticles and screened for their toxicity on Vero cell lines (ATCC ${ }^{\circledR}$ CCL-81 ${ }^{\mathrm{TM}}$ ). The cytotoxicity of nanoparticles was evaluated using the 3-[4.5-dimethylthiazol-2-yl]-2.5-diphenyltetrazolium bromide (MTT) (Sigma-Aldrich, M2128) assay, based on the reduction of the yellowish MTT to the insoluble and dark blue formazan by viable and metabolically active cells [26]. Vero cells were cultured in Dulbecco's modified Eagle's medium (DMEM), $2 \mathrm{mM}$ glutamine, $100 \mu \mathrm{g} / \mathrm{mL}$ penicillin, $0.1 \mathrm{mg} / \mathrm{mL}$ streptomycin, and $10 \%$ fetal calf serum in a $5 \% \mathrm{CO}_{2}$ in incubator, seeded at $5 \times 10^{3}$ cells/well in 96-well plates and incubated for $24 \mathrm{~h}$ at $37^{\circ} \mathrm{C}$ in $5 \% \mathrm{CO}_{2}$. AgNPs and $\mathrm{CH}-\mathrm{AgNPs}$ were tested at $50 \mu \mathrm{g} / \mathrm{mL}$ concentration followed by 2 -fold dilution. After $24 \mathrm{~h}$ of incubation, $100 \mu \mathrm{L}$ of MTT solution was added to cells and incubated for $3 \mathrm{~h}$ at $37^{\circ} \mathrm{C}$ in $5 \%$ of $\mathrm{CO}_{2}$. Further MTT solution was removed and $100 \mu \mathrm{L}$ dimethyl sulfoxide (DMSO) was added followed by incubation for $10 \mathrm{~min}$ at room temperature to dissolve the formazan crystals. Finally, the absorbance was measured at $540 \mathrm{~nm}$ and the data were analyzed. The experiment was corroborated by comparison to an untreated control (cells not treated with any compound).

\subsection{Evaluation of Antibacterial Activity}

MIC values of the nanoparticle suspensions were determined using the microdilution method, conducted in 96-well plates. The studies were performed in accordance with the Clinical and Laboratory Standards Institute (CLSI). Each substance was serially diluted to obtain concentrations in the range of 0.78 to $100 \mu \mathrm{g} / \mathrm{mL}$. Ampicillin and vancomycin (ranging from 0.25 to $4 \mu \mathrm{g} / \mathrm{mL}$ ) were used as a positive control for Gram-negative and Gram-positive bacteria, respectively. Untreated bacteria were used as negative control. Bacterial suspensions were adjusted to contain approximately $1 \times 10^{6} \mathrm{CFU} / \mathrm{mL}$ of bacteria. A volume of $50 \mu \mathrm{L}$ of the inoculum was added to the wells, obtaining a concentration of $5 \times 10^{5} \mathrm{CFU} /$ well. The plates were then incubated at $37^{\circ} \mathrm{C}$ for $20 \mathrm{~h}$.

Medium turbidity was measured using a microtiter plate reader (Sunrise, Tecan Austria $\mathrm{GmbH}$, Austria) at $595 \mathrm{~nm}$. MIC is the lowest concentration of a compound which causes 100\% inhibition of microbial growth. All experiments were performed in triplicate, and values are reported as mean \pm standard deviation.

\subsection{Statistical Analysis}

All analytical determinations were performed in triplicate, and the results are expressed as mean \pm standard deviation. The statistical significance was assessed by GraphPad InStat 3 software (GraphPad Software, CA, USA), at a significance threshold value of $p<0.05$.

\section{Results}

\subsection{Characterization and Identification of $\mathrm{CH}-\mathrm{AgNPS}$}

After mixing Prunus cerasus leaf extract with $\mathrm{AgNO}_{3}$ solution, we observed a color change from colorless to brown and yellowish brown, which indicates the formation of AgNPs and CH-AgNPs, respectively. The synthesis of AgNPs and CH-AgNPs were confirmed via UV-Vis spectroscopy analysis. UV-Vis spectra of nanoparticles were recorded in the range of 200-800 nm. UV-Vis spectra of AgNPs and CH-AgNPs exhibited a peak at 429 and $445 \mathrm{~nm}$, respectively, which is mainly due to the surface plasmon resonance of nano forms of silver (Figure 1). 


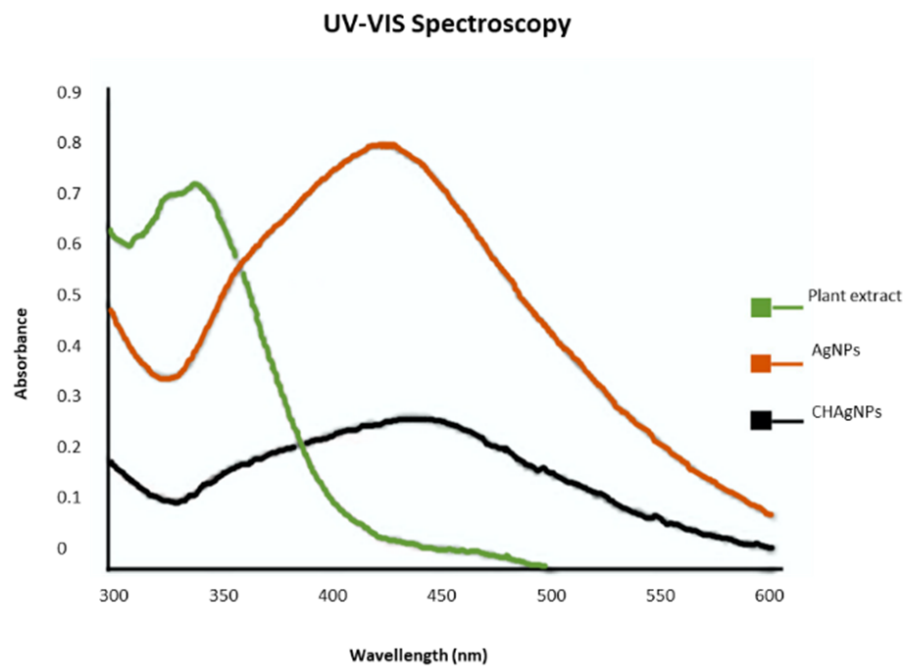

Figure 1. UV-Vis absorption spectra of synthesized AgNPs (429 nm) and CH-AgNPs (445 nm).

The second step in physicochemical characterization is the average particle size distribution by dynamic light scattering (DLS). The data highlighted that the average sizes of AgNPs and CH-AgNPs were 32.16 and $50 \mathrm{~nm}$, respectively, with a polydispersity index of 0.2 (Figure 2a,b). The increase in CH-AgNP size is due to the chitosan coating AgNPs. We further investigated our biologically synthesized AgNPs and CH-AgNPs with surface charge definition via zeta potential analysis. The results indicate that AgNPs had a charge of $-7.20 \mathrm{mV}$, while $\mathrm{CH}$-AgNPs scored a value of $9 \mathrm{mV}$, with both measurements indicating the nanoparticles were stable (Figure 3a,b).
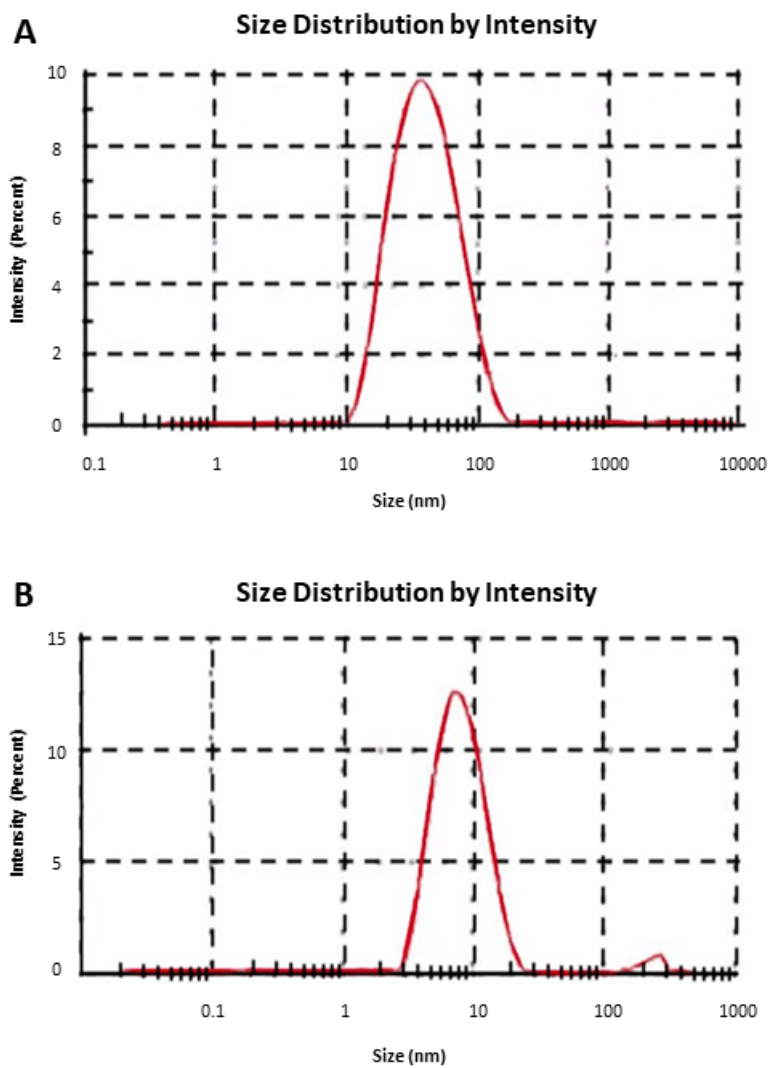

Figure 2. Particle size distribution of synthesized (A) silver nanoparticles (32.16 nm) and PDI (0.2), and (B) silver chitosan nanoparticles (50 nm) and PDI (0.2). 


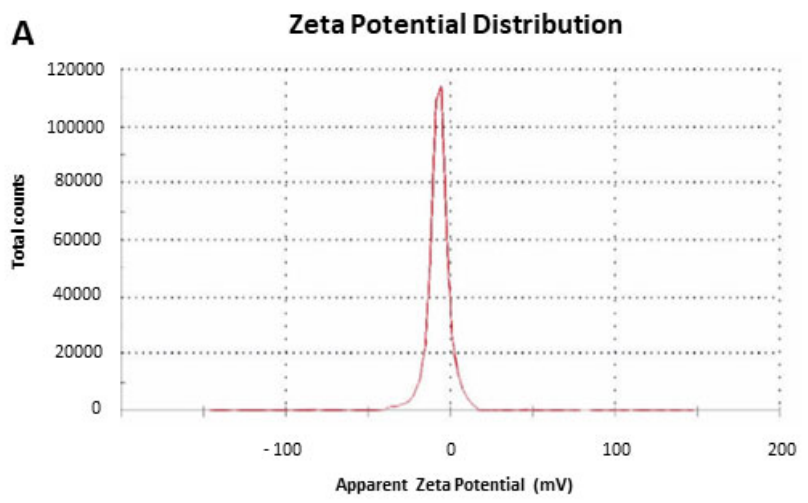

B Zeta Potential Distribution

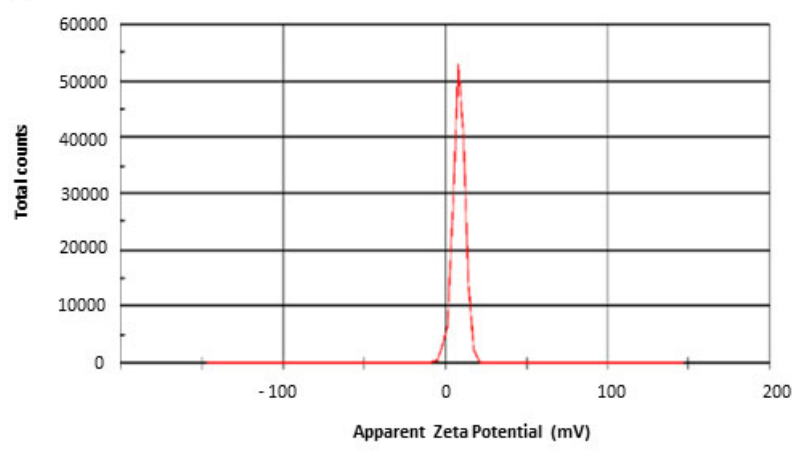

Figure 3. Zeta potential analysis of (A) AgNPs $(-7.20 \mathrm{mV})$ and $(\mathbf{B}) \mathrm{CH}-\mathrm{AgNPs}(9 \mathrm{mV})$.

\subsection{FT-IR Analysis of Biosynthesized CH-AgNPs}

T-IR analysis of AgNPs and CH-AgNPs was performed in order to confirm the reduction of the molecular interaction and capping agent which is responsible for synthesizing and stabilizing the nanoparticles. This approach is generally used for qualitative analysis of nanostructures. FT-IR spectra of AgNPs shows peaks at 3280, 2856, 1527, 1295, 1017 and $823 \mathrm{~cm}^{-1}$ and a similar pattern for CH-AgNPs detected with peaks at 3178, 1653, 1509, 1381,1278 , and $1042 \mathrm{~cm}^{-1}$, respectively (Figure $\left.4 b, c\right)$. These peaks represent functional groups at different wavenumbers. The absorbance peak at $3280 \mathrm{~cm}^{-1}$ can be attributed to the vibrations of amino groups $(\mathrm{N}-\mathrm{H})$, which may be the presence of peptides, whereas the peak at $2856 \mathrm{~cm}^{-1}$ may be because of sym $-\mathrm{CH}_{3}$ stretching vibrations. However, the peak at $1527 \mathrm{~cm}^{-1}$ can be assigned to $\mathrm{C}=\mathrm{N}$ stretching vibration, and the peak at $1295 \mathrm{~cm}^{-1}$ may be because of $\mathrm{C}-\mathrm{H}$ deformation vibration. Similarly, the peak $1017 \mathrm{~cm}^{-1}$ can be assigned to $\mathrm{C}-\mathrm{O}$ stretching vibration and peak at $823 \mathrm{~cm}^{-1}$ may be because of $\mathrm{C}-\mathrm{C}$ skeletal vibration (Table 3). In case of CH-AgNPs, the peak at $3178 \mathrm{~cm}^{-1}$ is associated with amide group $\mathrm{N}-\mathrm{H}$ stretching. The vibration peak shown at $1653 \mathrm{~cm}^{-1}$ can be assigned to $\mathrm{C}=\mathrm{C}$ stretching vibrations. Moreover, a peak of $1509 \mathrm{~cm}^{-1}$ may be due to a broad amide II band. The peaks 1381,1278 , and $1042 \mathrm{~cm}^{-1}$ are assigned to $\mathrm{C}-\mathrm{H}$ deformation vibration sym, $\mathrm{C}-\mathrm{H}$ sym deformation vibration, and C-C skeleton vibration, respectively (Table 4). 
A

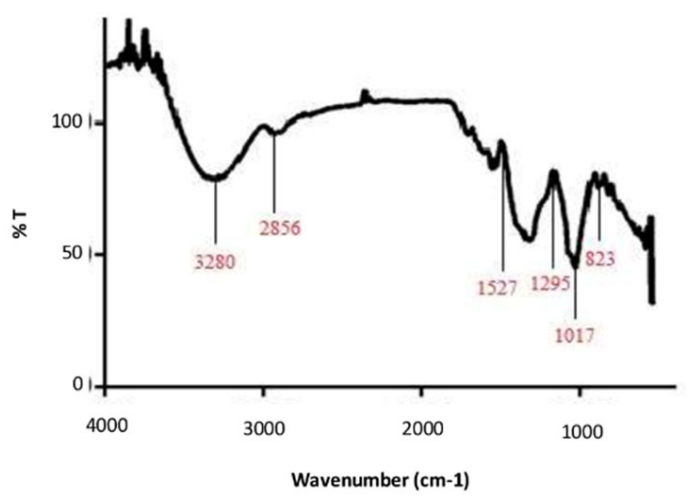

B

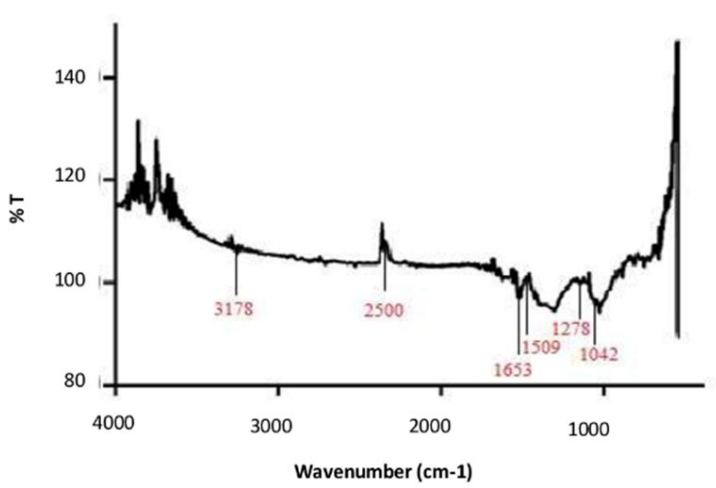

Figure 4. FT-IR analysis of (A) AgNPs and (B) FT-IR analysis of silver chitosan nanoparticles.

Table 3. FT-IR analysis of AgNPs.

\begin{tabular}{cccc}
\hline Sr No. & $\begin{array}{c}\text { FT-IR Peak }\left(\mathbf{c m}^{-\mathbf{1}}\right) \\
\text { at AgNPs }\end{array}$ & Functional Group & References \\
\hline 1 & 3280 & vibrations of amino groups $(\mathrm{N}-\mathrm{H})$ & Liu et al. 2013 [26] \\
2 & 2856 & sym $-\mathrm{CH}_{3}$ stretching vibration & Yang et al. 2000 [27] \\
3 & 1527 & $\mathrm{C}=\mathrm{N}$ stretching vibration & Nabedryk et al. 1986 [28] \\
4 & 1295 & $\mathrm{C}-\mathrm{H}$ deformation vibration & Yin et al. 2019 [29] \\
5 & 1017 & C-O stretching vibration & Ongen et al. 2012 [30] \\
6 & 823 & C-C skeletal vibration & Bollino et al. 2017 [31] \\
\hline
\end{tabular}

Table 4. FT-IR analysis of CH-AgNPs.

\begin{tabular}{cccc}
\hline Sr No. & $\begin{array}{c}\text { FT-IR Peak }\left(\mathbf{c m}^{-\mathbf{1}}\right) \\
\text { at CH-AgNPs }\end{array}$ & Functional Group & References \\
\hline 1 & 3178 & amide group N-H stretch & Ben-Refael 2020 [32] \\
2 & 1653 & C=C stretching vibration & Ye et al. 2007 [33] \\
3 & 1509 & broad amide II band & Service et al. 2010 [34] \\
5 & 1278 & C-H sym deformation vibration & Li et al. 2015 [35] \\
6 & 1042 & C-C skeleton vibration & Liu et al. 2013 [26] \\
\hline
\end{tabular}

\subsection{Transmission Electron Microscopy (TEM) Analysis of Biosynthesized CH-AgNPS}

Furthermore, TEM analysis confirmed that silver nanoparticles showed a spherical shape and polydisperse nature (Figure 5a,b). Interestingly, in the case of $\mathrm{CH}$-AgNPs, the morphology of particles was spherical with a thin chitosan coating surrounding the silver core (Figure $5 \mathrm{c}, \mathrm{d}$ ). Moreover, a homogeneous distribution of the chitosan coating around 
the silver nanostructures was observed via TEM micrographs. The absence of aggregation was detected when nanoparticles were analyzed; this clearly indicates that nanoparticles were completely coated by a polymer. Indeed, AgNPs coated with chitosan showed a clear layer surrounding their core.

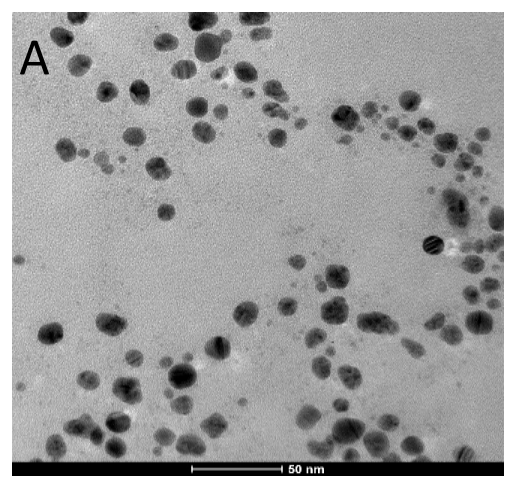

C

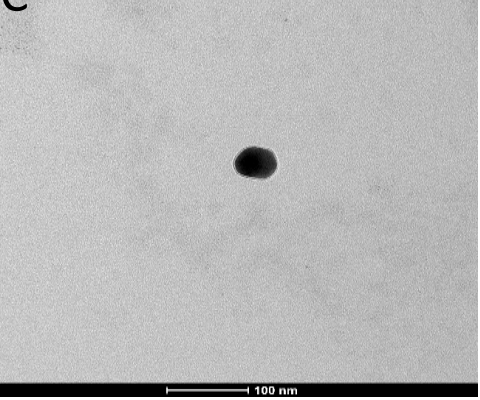

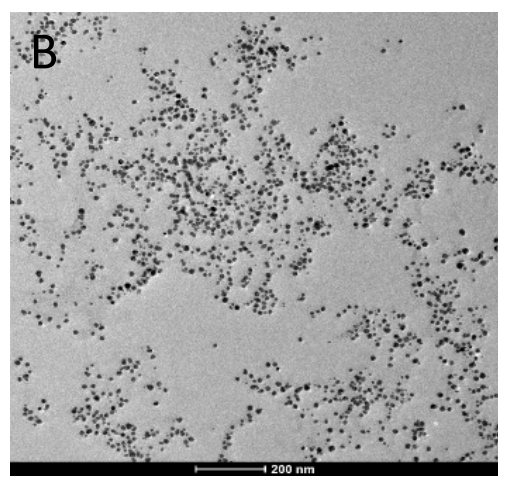

D

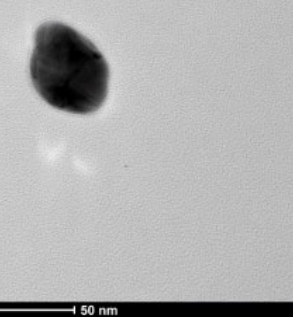

Figure 5. Transmission electron microscopy analysis of synthesized $\operatorname{AgNPs}(\mathbf{A}, \mathbf{B})$ and CH-AgNPs (C,D).

\subsection{Evaluation of Cytotoxic Activity}

One of the main goals of our study was the prospect of reducing the cellular toxicity of AgNPs and CH-AgNPs. In order to evaluate the chitosan contribution for this purpose, we investigated their effects on human cell lines. The MTT cell toxicity assay was performed against Vero cells treated with AgNPs and CH-AgNPs, respectively. Indeed, the data from the cell toxicity assay show that both the AgNPs and $\mathrm{CH}-\mathrm{AgNPs}$ did not exhibit remarkable toxic effects in terms of Vero cell viability, even at the highest tested concentration of $50 \mu \mathrm{g} / \mathrm{mL}$ (Figure 6).

\subsection{Evaluation of Antimicrobial Activity}

We achieved a decrease in toxic properties of AgNPs and CH-AgNPs prepared from Prunus cerasus via the green synthesis method. They were then evaluated for their antibacterial activity. As a system model for the assay, we used two different species for both Gram-positive and Gram-negative bacteria (Figure 7a,b). Among Gram-positive bacteria, ATCC, MS, and MDR strains of E. faecalis and S. aureus were selected. In addition, we selected the Gram-negative bacteria ATCC, MS, and MDR strains of E. coli and K. pneumoniae. The antibacterial properties were evaluated using the microdilution method. The CH-AgNP have MICs ranging from 6.5 to $50 \mu \mathrm{g} / \mathrm{mL}$ and 12.5 to $25 \mu \mathrm{g} / \mathrm{mL}$ against the Gram-positive and Gram-negative strains, respectively. On the contrary, AgNPs have higher MICs as compared to CH-AgNPs; i.e., for Gram-positive strains, the MICs range from 100 to $12.5 \mu \mathrm{g} / \mathrm{mL}$ and for Gram-negative 50 to $12.5 \mu \mathrm{g} / \mathrm{mL}$. The MIC of CH-AgNPs was significantly lower than that of bare AgNPs $(p<0.05)$. The MIC of CH-AgNP against Gram-negative bacteria ATCC, MDR, and MS strains was 12.5, 25, and $12.5 \mu \mathrm{g} / \mathrm{mL}$, respectively. In the case of Gram-positive bacteria, E. faecalis ATCC, MDR, and MS strains have MICs of 6.5, 12.5, and 
$25 \mu \mathrm{g} / \mathrm{mL}$, respectively. S. aureus ATCC 6538, MDR, and MS strains have MICs of 25 and $50 \mu \mathrm{g} / \mathrm{mL}$, respectively. The high performance of $\mathrm{CH}-\mathrm{AgNP}$ could be attributed to the presence of $\mathrm{Ag}^{+}$and also positively charged groups in the chitosan structure. However, the Prunus cerasus leaf extract and chitosan solutions did not show any antimicrobial effect against bacteria.

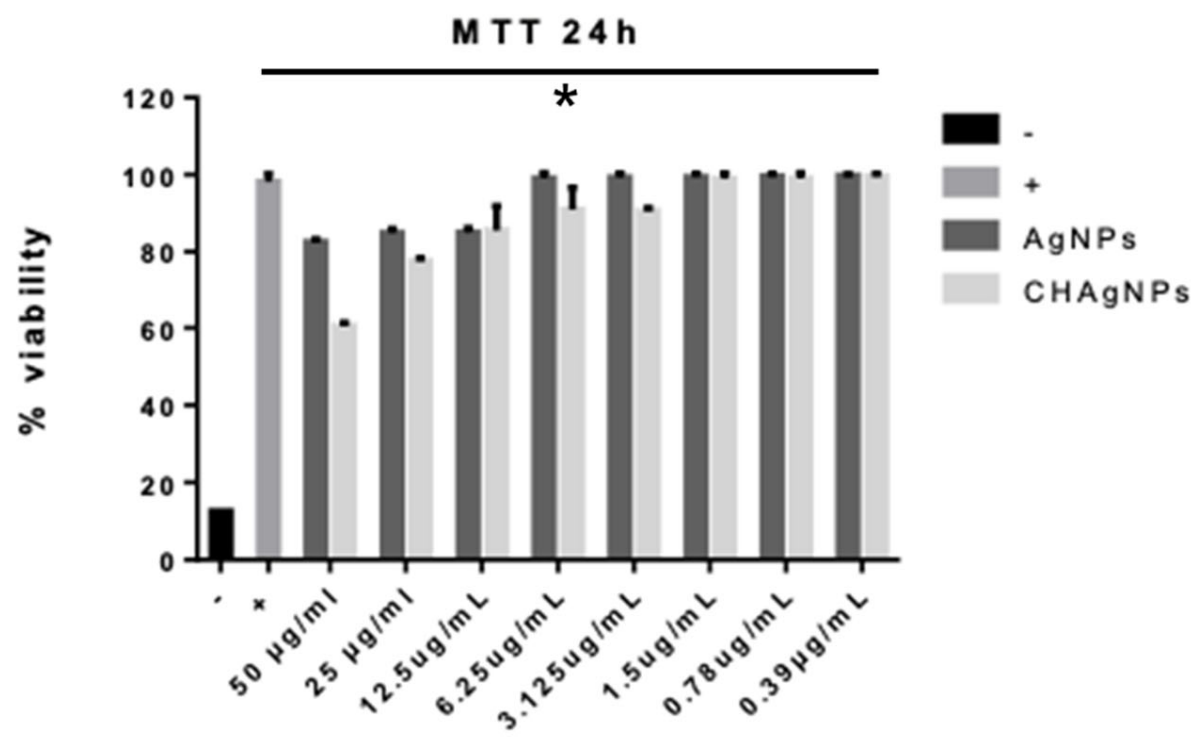

Figure 6. MTT assay on Vero cells treated with different concentrations of AgNPs and CH-AgNPs for $24 \mathrm{~h}$.- - refers to the negative control, i.d. cells treated with DMSO; + indicates positive control that corresponds to cells not treated with any compound. ${ }^{*} p<0.05$.

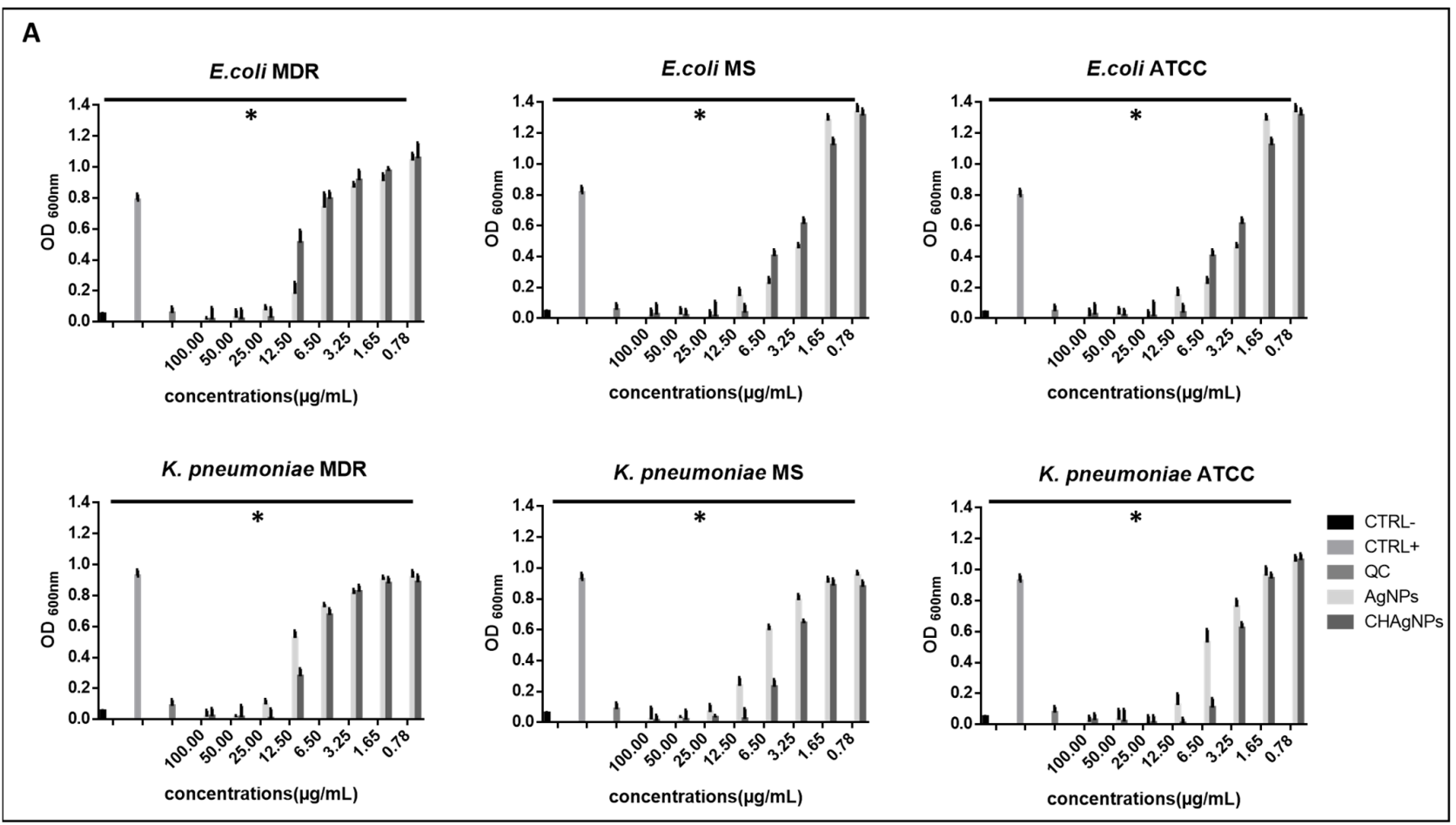

Figure 7. Cont. 


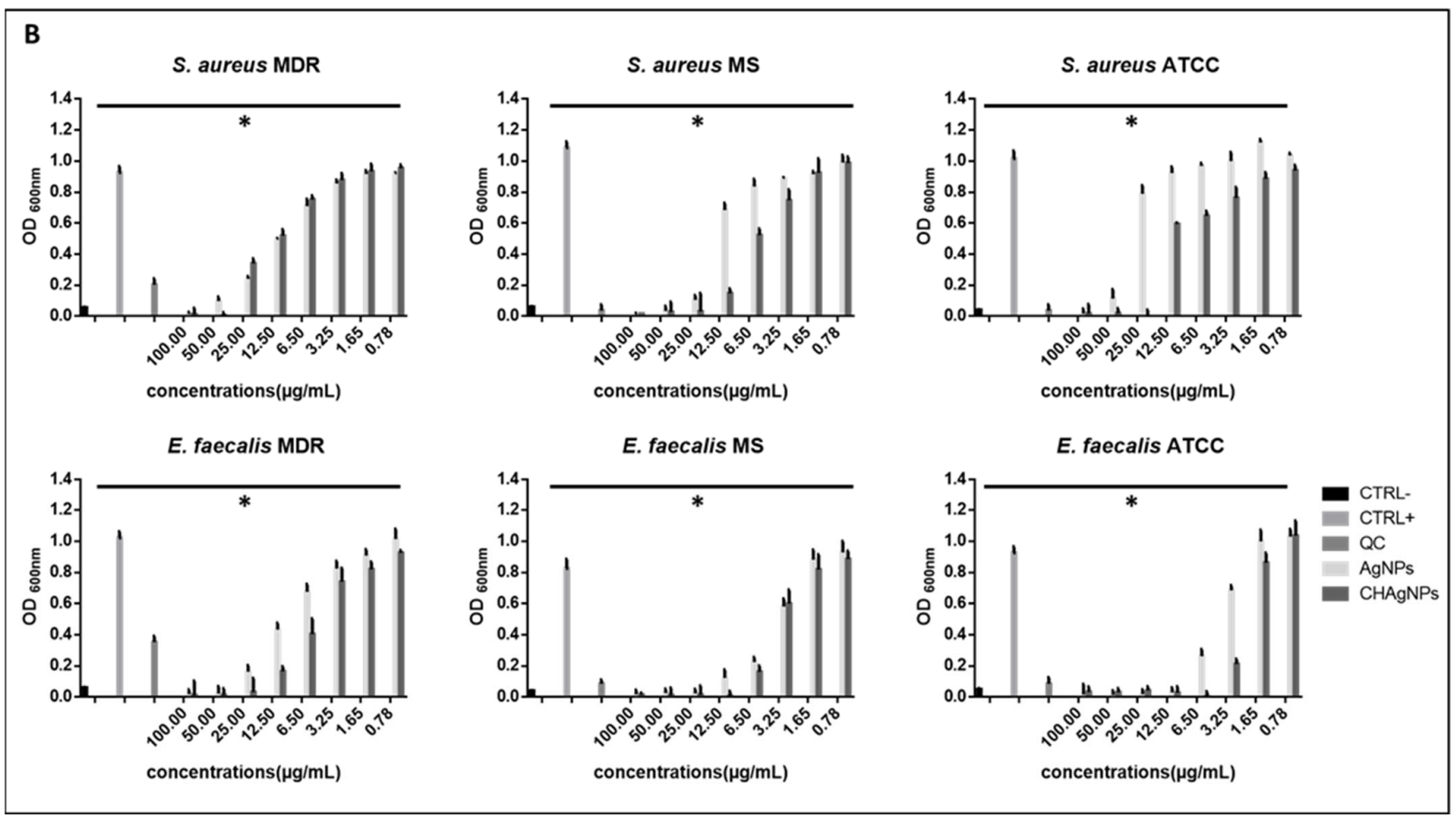

Figure 7. Antibacterial activity of nanoparticles against (A) a panel of Gram-negative bacteria: E. coli ATCC, E. coli MS, E. coli MDR, K. pneumoniae ATCC, K. pneumoniae MS, and K. pneumoniae MDR; (B) S. aureus ATCC, S. aureus MS, S. aureus MDR, E. faecalis ATCC, E. faecalis MS, and E. faecalis MDR. * $p<0.05$.

\section{Discussion}

Although the use of silver and silver salts as antibacterial agents is an ancient method, silver nanoparticle (AgNP) fabrication has only recently been developed. Silver nanoparticles are well known for their antimicrobial activity, and there are also reports of their acute and chronic toxicity [36,37]. With this in mind, nanoparticles were obtained via green synthesis with the addition of compounds/peptides/chemical groups on their surfaces. This method is able to reduce toxicity to allow the application of nanoparticles in the treatment of human infectious diseases. Among the possible coatings, chitosan-coated silver nanoparticles have attracted significant attention in the biomedical field because of their unique biodegradable, biocompatible, nontoxic, and antimicrobial nature [38]. Many scientists have reported that chitosan has a strong affinity for metal ions as a result of a large number of amino and hydroxyl groups. In a study conducted by Nate et al. (2018), the role of the chitosan amino group was defined as being crucial for metal ion release and the formation of $\mathrm{CH}-\mathrm{AgNPs}$ [39]. Plants represent the main source for NP synthesis. Several studies have demonstrated that the polyphenols present in plant extracts play a major role in the reduction of $\mathrm{Ag}^{+}$ions [40]. In the present study, the antibacterial effect of $\mathrm{CH}-\mathrm{AgNPs}$ prepared using Prunus cerasus leaf extract was assessed. The multitude of bioactive compounds present in Prunus cerasus makes it an excellent candidate for the synthesis of nanoparticles [41]. Moreover, the synthesis of metal nanoparticles using Prunus cerasus has not been explored to any great extent.

The results of UV-visible spectroscopy obtained in our study revealed a difference in size between $\mathrm{AgNPs}$ and $\mathrm{CH}-\mathrm{AgNPs}$. The $\mathrm{CH}-\mathrm{AgNPs}$ were larger than uncoated AgNPs since layers of chitosan were observed to be wrapped around AgNPs, as in the work described by Lim et al. (2013) [42]. The zeta potential on the surface of nanoparticles indicates the particles are stable. Nanoparticles possessing higher negative or positive zeta potentials will tend to repel each other and do not form aggregates [43,44]. Our synthesized nanoparticles were found to be more stable than those previously reported in studies [45]. In the current study, the FT-IR analysis showed that numerous amino groups act as capping 
agents. The results clearly indicate that these identified amino groups are responsible for the interaction with the metal surface, acting as capping sites for AgNP stabilization [46]. From the results, it can be concluded that capping agents allow proteins to bind to AgNPs by the electrostatic attraction of negatively charged carboxylate groups present in the protein secreted by plants [47]. Many of the peaks observed in the IR spectra of AgNPs and $\mathrm{CH}-$ AgNPs are closely associated with flavonoids and terpenoids, suggesting the adsorption of these molecules on the nanoparticle surface. The presence of several functional groups can influence the reduction of metal ions into corresponding metal nanoparticles. Using TEM analysis, we observed the presence of polydisperse nanoparticles [45]. The TEM images clearly indicated a difference in average size, which were 32 and $50 \mathrm{~nm}$ for AgNPs and $\mathrm{CH}-\mathrm{AgNPs}$, respectively. The cytotoxicity of synthesized AgNPs and $\mathrm{CH}-\mathrm{AgNPs}$ was screened in order to define the optimal concentrations for antimicrobial assays. The results reveal that $\mathrm{CH}-\mathrm{AgNPs}$ did not show any relevant cytotoxicity against the Vero cell line for each tested concentration. We observed that CS-AgNPs at $312.5 \mu \mathrm{g} / \mathrm{mL}$ did not exhibit any cytotoxicity against L-929 fibroblast cells as has been previously reported [48]. The antibacterial potential of $\mathrm{CH}-\mathrm{AgNPs}$ was evaluated against standard and clinically isolated Gram-positive and Gram-negative isolates. The $\mathrm{CH}$-AgNPs efficiently inhibited bacterial growth compared to AgNPs. Our findings show that the MIC values of $\mathrm{CH}-\mathrm{AgNPs}$ were lower than those of AgNPs. Within the same species, the coated nanoparticles exhibited a different effect between the various strains. A lower MIC value was recorded for the MDR strains. The stronger structural properties of the MDR strains could justify the lower MIC values recorded [49]. The present antimicrobial evaluation studies agreed with the reports of Asghar et al. 2020 [44]. Therefore, it could be assumed that the use of CH-AgNPs at their MIC value can effectively inhibit the growth of bacteria while not being toxic to normal cells. The mechanism of action for the antibacterial activity of chitosan might come from the contact-inhibitory mechanism between negatively charged teichoic acid in the peptidoglycan layer on the bacterial surface and the positively charged protonated amine moieties on the chitosan backbone [50]. Similar studies reported that the enhanced antibacterial activity of $\mathrm{CH}-\mathrm{AgNPs}$ is due to the synergistic antibacterial potential of AgNPs with chitosan [51]. It is notable that metal NPs have more relevant bactericidal effects due to their high affinity with the active surface groups of microbial strains [52]. Similarly, it has been suggested that chitosan reacts with both the bacterial cell wall and the cell membrane [53].

\section{Conclusions}

The simple and rational exploitation of a green synthesis procedure was used to produce biogenic silver nanoparticles and silver nanoparticles conjugated with chitosan. On the basis of obtained results, the combination of chitosan with AgNPs against Grampositive and Gram-negative bacteria offers a valuable contribution to nanomedicine. In vitro studies show that the chitosan-coated AgNPs exhibited substantial activity against ATCC, MS, and MDR strains. According to these findings, this nanoconjugate system may provide a frugal method for the development of a new generation of effective antibacterial agents. These outcomes open new avenues in the formulation of $\mathrm{CH}-\mathrm{AgNPs}$ for in vivo studies in animal models in our future research.

Author Contributions: Conceptualization, M.G. (Massimiliano Galdiero) and G.F.; methodology, S.S., V.F., C.Z., A.C. and A.M.; validation, L.R., V.F. and C.Z.; formal analysis, A.F. and L.R.; investigation, resources, S.S., G.F. and M.P.; writing-original draft preparation, S.S, V.F. and C.Z.; writing—review and editing G.F. and A.D.F.; supervision, M.G. (Marilena Galdiero), G.F and M.G. (Massimiliano Galdiero); project administration, M.G. (Massimiliano Galdiero). All authors have read and agreed to the published version of the manuscript.

Funding: This research received no external funding.

Institutional Review Board Statement: Not applicable. 
Informed Consent Statement: Not applicable, no study involving humans was performed in this research.

Data Availability Statement: The data presented in this study are available on request from the corresponding author. The data are not publicly available since a public repository was not required for this project.

Conflicts of Interest: The authors declare no conflict of interest.

\section{References}

1. Schmieder, R.; Edwards, R. Insights into antibiotic resistance through metagenomic approaches. Future Microbiol. 2019, 7, 73-89. [CrossRef]

2. Matsushita, T.; Sati, G.C.; Kondasinghe, N.; Pirrone, M.G.; Kato, T.; Waduge, P.; Kumar, H.S.; Sanchon, A.C.; Dobosz-Bartoszek, M.; Shcherbakov, D.; et al. Design, multigram synthesis, and in vitro and in vivo evaluation of propylamycin: A semisynthetic 4, 5-deoxystreptamine class aminoglycoside for the treatment of drug-resistant Enterobacteriaceae and other Gram-negative pathogens. J. Am. Chem. Soc. 2019, 141, 5051-5061. [CrossRef]

3. Yoshida, A.; Sasaki, H.; Toyama, T.; Araki, M.; Fujioka, J.; Tsukiyama, K.; Hamada, N.; Yoshino, F. Antimicrobial effect of blue light using Porphyromonas gingivalis pigment. Sci. Rep. 2017, 7, 1-9. [CrossRef]

4. Santella, B.; Folliero, V.; Pirofalo, G.M.; Serretiello, E.; Zannella, C.; Moccia, G.; Santoro, E.; Sanna, G.; Motta, O.; De Caro, F. Sepsis-A retrospective cohort study of bloodstream infections. Antibiotics 2020, 9, 851. [CrossRef]

5. Ravishankar Rai, V.; Jamuna Bai, A. Nanoparticles and their potential application as antimicrobials, Science against Microbial Pathogens: Communicating Current Research and Technological Advances. In Microbiology Series; Méndez-Vilas, A., Ed.; Formatex: Budapest, Hungary, 2011; Volume 3, pp. 197-209.

6. Franci, G.; Falanga, A.; Galdiero, S.; Palomba, L.; Mahendra, R.; Morelli, G.; Galdiero, M. Silver nanoparticles as potential antibacterial agents. Molecules 2015, 20, 8856-8874. [CrossRef]

7. Zannella, C.; Shinde, S.; Vitiello, M.; Falanga, A.; Galdiero, E.; Fahmi, A.; Santella, B.; Nucci, L.; Gasparro, R.; Galdiero, M.; et al. Antibacterial activity of indolicidin-coated silver nanoparticles in oral disease. Appl. Sci. 2020, 10, 1837. [CrossRef]

8. Othman, A.M.; Elsayed, M.A.; Al-Balakocy, N.G.; Hassan, M.M.; Elshafei, A.M. Biosynthesis and characterization of silver nanoparticles induced by fungal proteins and its application in different biological activities. J. Genet. Eng. Biotechnol. 2019, 17, 1-13. [CrossRef]

9. Rozykulyyeva, L.; Astuti, S.D.; Zaidan, A.H.; Pradhana, A.A.S.; Puspita, P.S. Antibacterial activities of green synthesized silver nanoparticles from Punica granatum peel extract. AIP Conf. Proc. 2020, 2314, 060012.

10. Loo, Y.Y.; Rukayadi, Y.; Nor-Khaizura, M.; Kuan, C.H.; Chieng, C.W.; Nishibuchi, M.; Radu, S. In Vitro antimicrobial activity of green synthesized silver nanoparticles against selected Gram-negative foodborne pathogens. Front. Microbiol. 2018, 16, 1555. [CrossRef]

11. Rai, M.K.; Deshmukh, S.; Ingle, A.; Gade, A. Silver nanoparticles: The powerful nanoweapon against multidrug-resistant bacteria. J. Appl. Microbiol. 2012, 112, 841-852. [CrossRef]

12. Rout, Y.; Behera, S.; Ojha, A.K.; Nayak, P. Green synthesis of silver nanoparticles using Ocimum sanctum (Tulashi) and study of their antibacterial and antifungal activities. J. Microbiol. Antimicrob. 2012, 4, 103-109. [CrossRef]

13. Pironti, C.; Dell'Annunziata, F.; Giugliano, R.; Folliero, V.; Galdiero, M.; Ricciardi, M.; Motta, O.; Proto, A.; Franci, G. Comparative analysis of peracetic acid (PAA) and permaleic acid (PMA) in disinfection processes. Sci. Total Environ. 2021, 797, 149206. [CrossRef]

14. Thakkar, K.; Mhatre, S.; Parikh, R. Biological synthesis of metallic nanoparticles. Nanomed. Nanotechnol. Biol. Med. 2010, 6, 257-262. [CrossRef]

15. Rai, M.; Yadav, A.; Gade, A. Silver nanoparticles as a new generation of antimicrobials. Biotechnol. Adv. 2009, 27, 76-83. [CrossRef]

16. Singh, J.; Kaur, G.; Kaur, P.; Bajaj, R.; Rawat, M. A review on green synthesis and characterization of silver nanoparticles and their applications: A green nanoworld. World J. Pharm. Pharm. Sci. 2016, 7, 730-762.

17. Patra, S.; Mukherjee, S.; Barui, A.K.; Ganguly, A.; Sreedhar, B.; Patra, C.R. Green synthesis, characterization of gold and silver nanoparticles and their potential application for cancer therapeutics. Mater. Sci. 2015, 53, 298-309. [CrossRef]

18. Potara, M.; Jakab, E.; Damert, A.; Popescu, O.; Canpean, V.; Astilean, S. Synergistic antibacterial activity of chitosan-silver nanocomposites on Staphylococcus aureus. Nanotechnology 2011, 22, 135101. [CrossRef]

19. Ambrogi, V.; Donnadio, A.; Pietrella, D.; Latterini, L.; Alunni Proietti, F.; Marmottini, F.; Padeletti, G.; Kaciulis, S.; Giovagnoli, S.; Ricci, M. Chitosan films containing mesoporous SBA-15 supported silver nanoparticles for wound dressing. J. Mater. Chem. 2014, 2, 6054-6063. [CrossRef]

20. Luna-Hernández, E.; Cruz-Soto, M.; Padilla-Vaca, F.; Mauricio-Sánchez, R.A.; Ramirez-Wong, D.; Munoz, R.; Granados-López, L.; Ovalle-Flores, L.R.; Menchaca-Arredondo, J.L.; Hernández-Rangel, A.; et al. Combined antibacterial/tissue regeneration response in thermal burns promoted by functional chitosan/silver nanocomposites. Int. J. Biol. Macromol. 2017, 105, 1241-1249. [CrossRef]

21. Monda, V.; Valenzano, A.; Moscatelli, F.; Messina, A.; Piombino, L.; Zannella, C.; Viggiano, E.; Monda, G.; De Luca, V.; Chieffi, S.; et al. Modifications of activity of autonomic nervous system, and resting energy expenditure in women using hormonereplacement therapy. Biol. Med. 2016, 8, 5. 
22. Vargas, M.; Albors, A.; Chiralt, A.; González-Martínez, C. Quality of cold-stored strawberries as affected by chitosan-oleic acid edible coatings. Postharvest Biol. Technol. 2006, 41, 164-171. [CrossRef]

23. Chien, P.J.; Sheu, F.; Lin, H.-R. Coating citrus (Murcott tangor) fruit with low molecular weight chitosan increases postharvest quality and shelf life. Food Chem. 2007, 100, 1160-1164. [CrossRef]

24. Ishihara, M.; Nguyen, V.Q.; Mori, Y.; Nakamura, S.; Hattori, H. Adsorption of silver nanoparticles onto different surface structures of chitin/chitosan and correlations with antimicrobial activities. Int. J. Mol. Sci. 2015, 16, 13973-13988. [CrossRef]

25. Zhang, X.; Liu, Z.; Shen, W.; Gurunathan, S. Silver Nanoparticles: Synthesis, Characterization, Properties, Applications, and Therapeutic Approaches. Int. J. Mol. Sci. 2016, 17, 1534. [CrossRef]

26. Liu, Y. Recent progress in fourier transform infrared (FTIR) spectroscopy study of compositional, structural and physical attributes of developmental cotton fibers. Materials 2013, 6, 299-313. [CrossRef]

27. Yang, H.; Irudayaraj, J. Characterization of semisolid fats and edible oils by Fourier transform infrared photoacoustic spectroscopy. J. Am. Oil Chem. Soc. 2000, 77, 291-295. [CrossRef]

28. Nabedryk, E.; Breton, J. Polarized Fourier transform infrared (FTIR) difference spectroscopy of the M412 intermediate in the bacteriorhodopsin photocycle. FEBS Lett. 1986, 202, 356-360. [CrossRef]

29. Yin, Y.; Yin, H.; Wu, Z.; Caiwen, Q.I.; Tian, H.; Zhang, W.; Hu, Z.; Feng, L. Characterization of coals and coal ashes with high content using combined second-derivative infrared spectroscopy and Raman spectroscopy. Crystals 2019, 9, 513. [CrossRef]

30. Ongen, A.; Ozcan, H.K.; Ozbas, E.E.; Balkaya, N. Adsorption of Astrazon Blue FGRL onto sepiolite from aqueous solutions. Desalination Water Treat. 2012, 40, 129-136. [CrossRef]

31. Bollino, F.; Armenia, E.; Tranquillo, E. Zirconia/hydroxyapatite composites synthesized via Sol-Gel: Influence of hydroxyapatite content and heating on their biological properties. Materials 2017, 10, 757. [CrossRef]

32. Ben-Refael, A.; Benisti, I.; Paz, Y. Transient photoinduced phenomena in graphitic carbon nitride as measured at nanoseconds resolution by step-scan FTIR. Catal. Today 2020, 340, 97-105. [CrossRef]

33. Ye, M.; Zhang, Q.-L.; Li, H.; Weng, Y.-X.; Wang, W.-C.; Qiu, X.-G. Infrared spectroscopic discrimination between the loop and $\alpha$-helices and determination of the loop diffusion kinetics by temperature-jump time-resolved infrared spectroscopy for cytochrome c. Biophys. J. 2007, 93, 2756-2766. [CrossRef]

34. Service, R.J.; Hillier, W.; Debus, R.J. Evidence from FTIR difference spectroscopy of an extensive network of hydrogen bonds near the oxygen-evolving Mn4Ca cluster of photosystem II involving D1-Glu65, D2-Glu312, and D1-Glu329. Biochemistry 2010, 49, 6655-6669. [CrossRef]

35. Li, D.; Shi, Y.; Yi, S.L. Aging Process of Puer Black Tea Studied by FTIR Spectroscopy Combined with Curve-Fitting Analysis. Guang Pu Xue Yu Guang Pu Fen Xi 2015, 35, 1860-1863.

36. Dakal, T.; Kumar, A.; Majumdar, R.; Yadav, V. Mechanistic basis of antimicrobial actions of silver nanoparticles. Front. Microbiol. 2016, 7, 1831. [CrossRef]

37. Lekamge, S.; Miranda, A.F.; Abraham, A.; Li, V.; Shukla, R.; Bansal, V.; Nugegoda, D. The toxicity of silver nanoparticles (AgNPs) to three freshwater invertebrates with different life strategies: Hydra vulgaris, Daphnia carinata, and Paratya australiensis. Front. Environ. Sci. 2018, 6, 152. [CrossRef]

38. De Sousa Victor, D.; da Cunha Santos, A.M.; de Sousa, B.V.; de Araújo Neves, G.; Navarro de Lima Santana, L.; Rodrigues Menezes, R. A Review on Chitosan's Uses as Biomaterial: Tissue Engineering, Drug Delivery Systems and Cancer Treatment. Materials 2020, 13, 4995. [CrossRef]

39. Nate, Z.; Moloto, M.J.; Mubiayi, P.K.; Sibiya, P.N. Green synthesis of chitosan capped silver nanoparticles and their antimicrobial activity. MRS Adv. 2018, 3, 2505-2517. [CrossRef]

40. Tungmunnithum, D.; Thongboonyou, A.; Pholboon, A.; Yangsabai, A. Flavonoids and Other Phenolic Compounds from Medicinal Plants for Pharmaceutical and Medical Aspects: An Overview. Medicines 2018, 5, 93. [CrossRef]

41. Capanoglu, E.; Boyacioglu, D.; de Vos, R.C.H.; Hall, R.D.; Beekwilder, J. Procyanidins in fruit from Sour cherry (Prunus cerasus) differ strongly in chainlength from those in Laurel cherry (Prunus lauracerasus) and Cornelian cherry (Cornus mas). J. Berry Res. 2011, 1, 137-146. [CrossRef]

42. Lim, J.; Yeap, S.; Che, H.; Low, S. Characterization of magnetic nanoparticle by dynamic light scattering. Nanoscale Res. Lett. 2013, 8, 381. [CrossRef]

43. Bélteky, P.; Rónavári, A.; Igaz, N.; Szerencses, B.; Tóth, I.Y.; Pfeiffer, I.; Kiricsi, M.; Kónya, Z. Silver nanoparticles: Aggregation behavior in biorelevant conditions and its impact on biological activity. Int. J. Nanomed. 2019, 14, 667. [CrossRef]

44. Bilal, M.; Zhao, Y.; Rasheed, T.; Ahmed, I.; Hassan, S.T.S.; Nawaz, M.Z.; Iqbal, H.M.N. Biogenic nanoparticle-chitosan conjugates with antimicrobial, antibiofilm, and anticancer potentialities: Development and characterization. Int. J. Environ. Res. Public Health 2019, 16, 598. [CrossRef]

45. Cinteza, L.O.; Scomoroscenco, C.; Voicu, S.N.; Nistor, C.L.; Nitu, S.G.; Trica, B.; Jecu, M.L.; Pectu, C. Chitosan-stabilized Ag nanoparticles with superior biocompatibility and their synergistic antibacterial effect in mixtures with essential oils. Nanomaterials 2018, 8, 826. [CrossRef]

46. Kalaivani, R.; Maruthupandy, M.; Muneeswaran, T. Synthesis of chitosan mediated silver nanoparticles (Ag NPs) for potential antimicrobial applications. Front. Lab. Med. 2018, 2, 30-35. [CrossRef] 
47. Rathod, D.; Golinska, P.; Wypij, M.; Dahm, H.; Rai, M. A new report of Nocardiopsis valliformis strain OT1 from alkaline Lonar crater of India and its use in synthesis of silver nanoparticles with special reference to evaluation of antibacterial activity and cytotoxicity. Med. Microbiol. Immunol. 2016, 205, 435-447. [CrossRef] [PubMed]

48. Składanowski, M.; Golinska, P.; Rudnicka, K.; Dahm, H.; Rai, M. Evaluation of cytotoxicity, immune compatibility and antibacterial activity of biogenic silver nanoparticles. Med. Microbiol. Immunol. 2016, 205, 603-613. [CrossRef]

49. Dell'Annunziata, F.; Ilisso, C.P.; Dell'Aversana, C.; Greco, G.; Coppola, A.; Martora, F.; Dal Piaz, F.; Donadio, G.; Falanga, A.; Galdiero, M.; et al. Outer Membrane Vesicles derived from Klebsiella pneumoniae influence the miRNA expression profile in human bronchial epithelial BEAS-2B cells. Microorganisms 2020, 8, 1985. [CrossRef]

50. Vallapa, N.; Wiarachai, O.; Thongchul, N.; Pan, J.; Tangpasuthadol, V.; Kiatkamjornwong, S.; Hoven, V.P. Enhancing antibacterial activity of chitosan surface by heterogeneous quaternization. Carbohydr. Polym. 2011, 83, 868-875. [CrossRef]

51. Wei, D.; Sun, W.; Qian, W.; Ye, Y.; Ma, X. The synthesis of chitosan-based silver nanoparticles and their antibacterial activity. Carbohydr. Res. 2009, 344, 2375-2382. [CrossRef] [PubMed]

52. Reidy, B.; Haase, A.; Luch, A.; Dawson, K.A.; Lynch, I. Mechanisms of silver nanoparticle release, transformation and toxicity: A critical review of current knowledge and recommendations for future studies and applications. Materials 2013, 6, 2295-2350. [CrossRef] [PubMed]

53. Raafat, D.; Sahl, H. Chitosan and its antimicrobial potential—A critical literature survey. Microb Biotechnol. 2009,2 , 186-201. [CrossRef] [PubMed] 